\title{
The Influence of Entertainment on The Average Stay: Hotel Establishments in Terras De Trás-Os-Montes
}

\author{
Elsa Esteves and Daniela Cabeceiro
}

Polytechnic Instituteof Bragança, CITUR, Portugal

Correspondence should be addressed to: Elsa Esteves; elsaesteves@ipb.pt

Received date:5 January 2021; Accepted date:29 June 2021; Published date: 29 October 2021

Academic Editor: Luis Nobre Pereira

Copyright @ 2021. Elsa Esteves and Daniela Cabeceiro. Distributed under Creative Commons Attribution 4.0 International CC-BY 4.0

\begin{abstract}
The main objective of the present study is to analyze the contribution of entertainment to the average stay in hotel establishments in Terras de Trás-os-Montes (Portugal). In view of the purpose of the study, four specific objectives were considered: i) To identify the type of entertainment activities complementary to the hotel offer; ii) To identify the existence of partnerships with tourist entertainment agents; iii) To identify the activities practiced by guests; iv) To analyze the perception of hotel managers regarding the influence of entertainment on the average stay. Thus, a qualitative methodology was applied supported by semi-structured interviews with the hotel managers in the region under study, between March and May, 2019. Of the 33 hotel establishments in the region, only 13 participated in the study. The information from the interviews was treated individually, using content analysis. It was concluded that only $23 \%$ of hotel establishments offer entertainment activities to guests, namely, walking routes, boat trips, guided tours and jeep tours. About $39 \%$ have partnerships with local tourist entertainment companies. The activities practiced by guests are mostly coincident with the activities offered by hotel establishments, namely, hiking, boat trips, jeep tours and guided tours. The managers of the hotels unanimously agree that entertainment contributes to the increase of the average stay. This study intends to alert other hotel managers in the region towards the influence of offering entertainment on increasing the average stay of tourists, and the importance of creating partnerships with local tourist entertainment companies.
\end{abstract}

Keywords: Entertainment, Average stay, Hotel establishments, Terras de Trás-os-Montes.

\section{Introduction}

For Xu (2010) and Vogel (2014), entertainment is a subset of tourism products with the aim of providing an unforgettable experience, such as things that can stimulate, encourage and generate pleasant moments. Among the various agents involved in providing entertainment activities, tourist entertainment agents tourist entertainment companies and maritime-tour operators, as well as hotel

Cite this Article as: Elsa Esteves and Daniela Cabeceiro (2021)," The Influence of Entertainment on The Average Stay: Hotel Establishments in Terras De Trás-Os-Montes" Journal of EU Research in Business, Vol. 2021 (2021), Article ID 937937, DOI: 10.5171/2021.937937 
establishments are highlighted among others. The hotel industry must adapt to visitors who stopped looking for accommodation just to sleep (Souza, 2006), by implementing entertainment programs (Almeida, 2003). According to Cavallari (2006), hotel entertainment aims to provide moments of fun through providing a quality and diversified service. Thus, the purpose of entertainment is to increase the visitor's interest in the destination, occupy his free time and increase the length of his stay (Torres, 2004).

The region under study, Terras de Trás-osMontes (TTM), is located in the north of Portugal, consisting of nine counties and having 31 hotel establishments (Registo Nacional de Turismo, 2019). The region has so many environmental and geographic spaces convenient for various entertainment activities related to nature and adventure tourism and cultural tourism. Such activities can be planned by tourist entertainment agents or the visitors themselves (Esteves, 2015).

In this context, the present research's main objective is to analyze the contribution of entertainment to the average stay in hotel establishments in Terras de Trás-os-Montes. Thus, in the light of the objective of the study, a semi-structured interview was conducted with the hotel managers of hotel establishments in the TTM region. Of the 31 existing establishments, only 13 participated in the study, and data collection was carried out from March 29 to May 13, 2019. The data were analyzed in terms of content analysis.

The article is divided into four further parts: i) A theoretical framework; ii) The research methodology; iii) Presentation and discussion of the results; and iv) Conclusions.

\section{Theoretical framework}

The continuous growth of tourism in the world has caused an increasing competitiveness in the hotel industry, due to the high demand standard of tourists today (Dominici \& Guzzo, 2010). Hotels must offer multiple and high quality services to make sure that theirn guests are satisfied and they can later return to the hotels and even recommend these services (Choi \& Chu, 2001). Guests used to search for hotels just for the comfort of their rooms or for the catering service; however, nowadays, they search for unforgettable unique and authentic experiences during their stay (Souza, 2006; Tourism Planning and Development Institute, 2018). Thus, tourism enterprises, namely hotel establishments, had to adapt to this new trend by improving their facilities and implementing entertainment programs (Almeida, 2003). When choosing a hotel establishment, in addition to its category, location or prices, the importance of offering entertainment programs is highlighted. In the line of this thought, Dominici and Guzzo (2010) refer that guests highlight entertainment as a positive service that should be provided by the hotel.

Costa, Glinia, Goudas and Antoniou (2004) define hotel entertainment as leisure/entertainment, fitness and sports activities, as well as live entertainment. Offering hotel entertainment activities can add value to the existing offer and increase the occupancy rate in the establishment. The study by Albayrak, Caber and Oz (2016) proves that the level of satisfaction with the hotel entertainment is statistically related to the overall satisfaction of tourists, which may influence the average stay in the hotel. The average stay is measured according to the average number of nights that a customer stays in a hotel establishment (Pinto, 2009). Some authors (e.g.: Almeida, 2003; Gokovali, Bahar \& Kozak, 2007; Jacinto, 2003; Jacobsen, Gossling, Dybedal \& Skogheim, 2018) prove that the availability and practice of entertainment activities prolong the visitors' stay. Turismo de Portugal, I. P. (2013, p.43) states that " support for entrepreneurship in the context of developing tourist entertainment activities is particularly important, as it translates into services that add value to the offer, enriching the tourists' experience and increasing their average stay". Rodrigues, Santos and Oliveira (2019) also confirm the direct and significant relationship between offering tourist routes from hotels (hotel 
entertainment) and the increase in the average stay of tourists.

\section{Research methodology}

The main objective of the study is to analyze the contribution of entertainment to the average stay in hotel establishments in Terras de Trás-os-Montes. To meet this objective, four specific sub-objectives were defined, namely: i) To identify the type of entertainment activities complementary to the hotel offer; ii) To identify the existence of partnerships with tourist entertainment agents; iii) To identify the activities practiced by guests; and iv) To analyze the perception of hotel managers regarding the influence of entertainment on the average stay. For the qualitative investigation adopted in the present study, a semistructured interview script was conducted, based on the afore-mentioned objectives. The 31 hotels of the study region were contacted and only 13 hotels offered to collaborate, corresponding to $42 \%$ of the study's target population. The data collection instrument was applied in person from the hotel managers of TTM, between March and May, 2019.

The interview was structured in two parts. The first part included questions to identify the interviewees' profiles, namely, sociodemographic data (gender, age, educational qualifications, area of training, and how long they have been in the managerial position). In the second part, questions about entertainment and average stay of guests were included, in order to meet the specific objectives of the study.

For the treatment of the data, the interviews were transcribed, and an exploratory content analysis was performed. According to Ghiglione and Matalon (cit. in Coutinho, 2011), there are two types of content analysis: when there are already pre- defined categories before applying the analysis, and when there is no categorical intervention, it is exclusively an exploratory analysis. The present study applied an exploratory analysis to the collected data.

\section{Presentation and discussion of results}

The interviews were conducted in person with 13 hotel managers in Terras de Trás-osMontes. Since the interviews are confidential, the work doesn't reveal the names of the hotels that participated in the study, instead, they were numbered (e. g.: Hotel 1; Hotel 2; ...). The interview guide was structured in two parts: i) Questions that allow to identify the interviewee's profile; and ii) Questions that allow to answer the specific objectives of the study.

Considering the profile of hotel managers, it was concluded that about $62 \%$ are male and $39 \%$ are female, and mostly aged between 30 and 50 years old $(77 \%, n=10)$. Of the interviewees, two (15\%) have a master's degree, six (46\%) have a degree, two (15\%) have a secondary education, two (15\%) have a 3rd cycle and only one (8\%) has a 2nd cycle. Regarding the training area, Tourism ( $n=3,23 \%)$, Hotel Management ( $=2,15 \%)$ and Management $(n=2,15 \%)$ are the predominant areas, respectively. Of the interviewees, three (23\%) have been working for one year, four (31\%) for five years and two (15\%) for 11 years.

In the second part of the interview, questions were asked to meet the specific objectives of the study. In relation to the first specific objective (01) - To identify the type of entertainment activities complementary to the hotel offer, it was found that only three hotels out of the 13 respondents offer entertainment activities to guests. The activities offered are related to the regional and geographical context, as can be seen in the following transcripts:

"Yes, few but we offer some" (Hotel 1); "Yes. We offer tours to tourist sites, to the Fraga do Puio here in Picote, the Faia Alta here in Lamoso, visits to the Miranda museum, the SéCatedral, the boat in Miranda too and also here to the surrounding area of the Arribas do Douro" (Hotel 8); "Yes, we do. We offer boats, cruises, airplanes, planes, donkey rides and river trips" (Hotel 12). 
As for the promotion of entertainment activities, guests are made aware of them through the internet, pamphlets, on Facebook and by hotel receptionists. Pinheiro (2018) proves that the information provided by receptionists, in hotel establishments, can increase the stay of guests. As for the frequency of demand for activities, opinions are divided between 'all year' and 'in the summer'.

When asked why they didn't offer activities, the interviewees presented the following justifications:

"Because for that, I would have to create a specific tourist entertainment department" (Hotel 4); "(...) Because the typology and the dimension and the place where it is inserted do not allow us to have activities here to offer guests" (Hotel 5); "Because we don't have a leisure space (...) a green area (...) it's basically just because of this issue" (Hotel 6); "Punctually, that is, seasonally. We have some packages made, but all with help, we are not the promoters" (Hotel 7); "Because there are companies that carry out this activity" (Hotel 10); "We don't have the capacity for that. It doesn't have the capacity for facilities for this" (Hotel 11); "We lack a lot of resources, whether human resources or other resources, and people without resources cannot do anything" (Hotel 13).

Analyzing the infrastructures of the 31 hotel establishments in the region under study, it was found that only 20 hotels have infrastructures suitable for offering entertainment activities, namely, meeting rooms $(n=15)$, swimming pools $(n=8)$ and spas $(n=2)$. This situation may affect the offer of hotel entertainment activities, as having been proven by some of the interviewees. Figueiredo's study (2013) also established a relationship between the offer of hotel entertainment and the classification of the hotel (between 1 and 5 stars). In the region under study, the category of hotels is between 1 and 4 stars. In recommending a hotel establishment, the importance of the entertainment offer is highlighted as a complementary service to the hotel offer, and is considered a positive service that the hotel should provide (Dominici \& Guzzo, 2010).

With regard to the second specific objective (02) - To identify the existence of partnerships with tourist entertainment agents, it was verified that only five of the 13 hotels have partnerships, and it turns out that they are mostly tourist entertainment companies, with the exception of Museums, Geopark Terras de Cavaleiros and Quinta do
Pomar. Several reasons were mentioned by the hotels that don't have partnerships with any entity. Hotel 1 stated that it doesn't have partnerships due to the fact that the tourist entertainment companies are far away, which makes it difficult to establish partnerships. Hotel 4 also replied that it doesn't have partnership because - "(...) they don't exist, or rather, they didn't ask me for this same partnership. (...) It is something I don't have because I don't even know companies that want to do it. (...) But I'm open to them, knowing that some exist, but I don't know what kind of activities they promote and the way they promote them". The manager of Hotel 8 owns a boat that does sightseeing. Respondents at Hotel 9 and Hotel 11 reported that they don't have partnerships since most guests are workers. Hotel 10 stated that guests are looking for entertainment companies or asking for information at the reception.

Of the activities that are most practiced by guests, hotels identify nature and adventure tourism activities. They are sought after and adapted to the regional context and the local offer, as can be seen from the following citations:

"The ones that most look for are the walks, mainly to the Parque Natural de Montesinho and they are the ones that we do the most. Almost every weekend, we have trips to the Parque Natural de Montesinho. (...) I have the jeep almost every weekend. They pick up the guests and go on trips to Montesinho, inside the city and in the 
historic area (...) they walked around the city with the train. Also, if they came here to pick them up, they really liked it. It was an experience they liked" (Hotel 2); "What they are looking for most is the trip to Montesinho, which has a part that goes by jeep and another part on foot (...), Rio de Onor too (...) Since there were the 7 wonders of Rio de Onor, we won this prize. Rio de Onor and Montesinho is, at this moment, what they are most looking for (...) the time of the deer brama, there is a very beautiful walk at night, (...) that is, (...) when the deer are to date, they have a noise of its own and everything is beautiful and there are people who like to appreciate this type of nature" (Hotel 3); "It is also a visit to the village of Rio de Onor, Parque Natural de Montesinho and Puebla de Sanábria. Therefore, it is for those who are looking for more, because it is perhaps the most demarcated image that exists here in the region, with the exception of the Puebla de Sanábria that we always add to the people who will visit Rio de Onor" (Hotel 5); "Usually they look for walks during the spring. In winter, there is usually not much demand for outdoor tourist activities. (...) And later on for the summer, look for the activities that exist at Azibo" (Hotel 6); "What we are most looking for has to do with walking routes, that is, everything related to nature, extreme sports" (Hotel 7).

Outdoor activities, such as hiking and visits to the Parque Natural de Montesinho, the village of Rio de Onor and Puebla de Sanábria (Spain), as well as the radical activities on the river beach of Azibo, are the most popular activities sought by guests. As for the question regarding how guests are aware of existing or available entertainment activities, the answers are identical - by internet, pamphlets, Facebook and receptionists, as can be seen in the following transcripts:

"Through our website, through our social networks, Instagram, Facebook, local and national newspapers. (...) Through television, TV Record (...) direct contacts that we make with travel agencies (...)" (Hotel 2); "At the reception through the information given by the employee who is in charge. Anyone interested in making trips or visiting some place asks at the reception what the method is" (Hotel 3).

When asked about the importance they attach to partnerships, the five hotels unanimously agreed on the importance of attracting customers to the hotel and the region. Hotel 2 manager mentioned: "Much. They are essential. There are some that are easier to deal with. All have difficulties. In the case of tourist entertainment companies, the biggest difficulty is that there is no company that dedicates $100 \%$ to this activity". He also mentioned that he has difficulties with another partnership - museums: "Another one that I have a great difficulty with is museums. I think it was very important to partner with museums because it is culture. One of the demands of our territory is nature, gastronomy and culture. Bragança has a lot of culture. It has history and this is complicated because of the opening hours of museums; in some days they close, and other days, they don't even open".

Hotel 3 enhanced this importance as follows: "Very good because my company is a small company (...) and without these partnerships, our hotel would lose a lot (...)". Hotel 5 highlighted the partnerships as follows: "The importance is always to the maximum. Everything that is meant to enhance the fact that people stay in the city, help to spread the word about the city itself to others so they can return and even invest."

As for the third specific objective (03) - To identify the activities practiced by guests, two types of activities stand out: i) The activities offered by the hotel industry; and ii) The activities offered through partnerships with local agents. From the hotel entertainment offer, guests usually look for massages and boat trips. Among the activities most practiced by guests, through partnerships, nature and adventure tourism activities are identified, such as jeep trips to the Parque Natural de Montesinho, visits to the village of Rio de Onor (guided tours) and walking routes. Esteves (2015) confirms that walking and boat trips are the most 
sought after and practiced activities by visitors in Trás-os-Montes region.

Regarding the fourth specific objective (04) - To analyze the perception of hotel managers regarding the influence of entertainment on the average stay, the interviewees were approached with three questions: i) Do you think that the offer of entertainment can influence the average stay of guests? ii) What is the average stay of guests? iii) Do you have a strategy to increase the average stay of guests?

For the first question, respondents had to answer only with 'yes' or 'no' and justify their answers. Of the respondents, 11 were unanimous in agreeing that entertainment influences the average stay in the region, as seen in the following quote:

"Clear. Nobody goes to a destination because of a hotel. This is a definite point because the hotel may be the best hotel in the world, but nobody goes to the hotel alone. (...) In other words, being able to keep a tourist here for more days also depends a little on the entertainment that the hotel can offer. (...) Allied with the potential of the region, it is possible to have 2, 3, 4, 5 days spent here by the guests" (Hotel 2).

Of the three hotels that offer entertainment activities, the average stay reaches a maximum of four nights, compared to hotels that don't offer any entertainment activity, in which the average stay doesn't exceed two nights. The diversity and typology of the activities offered also condition the average stay. The hotel (Hotel 8), which registered an average stay of four nights, offers sightseeing tours, guided tours and boat trips. The two hotels that offer entertainment activities, but that don't exceed two nights, offer: i) Indoor activities, such as swimming pools, massages and outdoor jacuzzi (Hotel 1); and ii) Donkey rides and boat rides (Hotel 12).

In response to the second question, it was concluded that the average stay of guests doesn't exceed two nights, with the exception of Hotels 8 and 9, who stated that they can go up to four nights. Hotel 1 also mentioned that there are people who can stay 10 to 11 days, depending on the time of year.

Regarding the last question, only six of the 13 participants in the study answered that question. They referred to continuing to invest in existing activities (Hotel 1). Hotel 3 mentioned that: "(...) the municipality is collaborating with local businesses, hotels and restaurants, and is beginning to have fixed events, with specific dates, that people will be setting from one year to the next and come. It was something that didn't happen, (...) ". Hotel 5 pointed to partnerships with local entities, namely, the business sector, the Polytechnic Institute of Bragança, the Northeast Hospital Unit and the City Council. At the tourist level, "(...) it is always difficult because for a small city with what we have, although it is diverse, not everyone comes to look for the region of Bragança, for example, to visit the villages in the park in detail, go hiking, bike rides, etc." Hotel 6 stated that: "Not at the moment. (...) If the municipality proposes to help us in this possibility of having other types of activities together with the hotel units, yes, we have no problem in making partnerships. We aren't alone".

In general terms, the three strategic lines pointed out by the respondents are:

i) Continue to invest in the activities most sought after by guests;

ii) Take advantage of events promoted by the municipality;

iii) Establish partnerships with local entities.

The answer to the specific objective - 04, corroborates the studies by Almeida (2003), Jacinto (2003) and Torres (2004) regarding the availability of entertainment activities to prolong the average stay of visitors. Turismo de Portugal, I. P. (2013) also mentions that tourist entertainment activities increase the average stay of tourists. Alén, Nicolau, Losada and Domínguez (2014) identify the entertainment activities carried out at the destination as one of the variables that influence the permanence of visitors. 
Esteves study's (2015) confirms the relationship between entertainment and the average stay, namely, when one of the study's clusters is housed in hotels, and practices various outdoor entertainment activities, with a stay period of more than three days. Albayrak et al. (2016) confirm that the hotel entertainment activities can influence the average stay.

After an analysis of the questions in the interview script, an exploratory content analysis was carried out for each of the interviews. Two categories of words were defined - entertainment and average stay.

For the category - Entertainment, it appears that the words most mentioned by the interviewees are: activities, walks/hikes, partnership (s), Parque Natural de Montesinho and companies. The words 'entertainment' or 'tourist entertainment' are identified 8 times. Other words, such as 'experiences', 'packages' and 'tourists', were less pointed out by respondents. For the category - Average stay, the following words stand out: hotel (s), day (s), guest (s) and night (s). The words 'stay' or 'average stay' are referenced 8 times. Words like 'reception', 'seasonal' and 'tourism' have a lower reference.

\section{Conclusions}

The present study's main objective is to analyze the contribution of entertainment to the average stay in hotel establishments in the Terras de Trás-os-Montes. In view of the first specific objective of the study - to identify the type of entertainment activities complementary to the hotel offer, it was found that only three hotels out of the 13 respondents offer such activities, namely, hiking, boat trips, jeep tours and guided tours. In response to the second specific objective to identify the existence of partnerships with tourist entertainment agents, only five hotel managers mentioned partnerships with local tourist entertainment companies, among other entities in the region. As for the third specific objective - to identify the activities practiced by guests, the walking routes and guided tours, offered by the establishments and/or partner entities, stand out. For the fourth objective - to analyze the perception of hotel managers regarding the influence of entertainment on the average stay, the interviewees are unanimous in stating that the entertainment activities increase the average stay of the guests.

This research is considered to be a contribution to the managers of the hotel establishments in the region of the study, reflecting the assumed importance of entertainment in increasing the average stay of visitors. It is suggested that the hotels in Terras de Trás-os-Montes bet on creating and/or increasing partnerships with the various entities in the region, namely, entertainment companies and municipalities, among others. Investments should be made in offering and diversifying more entertainment activities, taking into account the needs of the target customers, along with improving the activities that already exist which are most sought after by visitors from the region.

Like any research work, there were some limitations during the course of this study, such as:

i) Lack of receptivity from hotel managers to collaborate in the study;

ii) Lack of information and knowledge of some hotel managers;

iii) Lack of comparative studies on the subject under analysis.

Finally, some future lines of research are pointed out as follows:

i) Apply the study to all hotels in the TTM region;

ii) Apply the study, in a quantitative approach, to guests and tourism entertainment agents;

iii) Develop an explanatory model of the entertainment impact on the average stay.

\section{References}

- Albayrak, T., Caber, M. and Oz, E. K. (2016),'Assessing Recreational Activities'Service Quality in Hotels: An Examination of Animation and Spa \& Wellness Services',Journal of Quality 
Assurance in Hospitality \& Tourism, 18(2), 218-234.

- Alén, E., Nicolau, J.L., Losada, N. and Domínguez, T. (2014),'Determinant factors of senior tourist length of stay', Annals of Tourism Research, 49, 19-32.

- Almeida, P. (2003), A Contribuição da Animação Turística para o Aumento das Taxas de Ocupação de Uma Região (Masters dissertation), Universidade de Aveiro, Aveiro.

- Cavallari, V. N. (2006), Recreação em ação, Ícone, São Paulo.

- Choi T. Y. and Chu R. (2001),'Determinants of hotel guests' satisfaction and repeat patronage in Hong Kong hotel industry', International Journal of Hospitality Management, 20, 277-297.

- Costa, G., Glinia, E., Goudas, M. and Antoniou, P. (2004),'Recreational services in resort hotels: customer satisfaction aspects',Journal of Sport \& Tourism, 9(2), 117-126.

- Coutinho, C. (2011), Metodologia de investigação em ciências sociais e humanas: teoria e prática,Edições Almedina, Coimbra.

- Dominici, G. andGuzzo, R. (2010),'Customer Satisfaction in the Hotel Industry: A Case Study from Sicily',International Journal of Marketing Studies, 2(2), 3-12.

- Esteves, E. (2015), Animação Turística como Fator de Eleição de um Destino Perspetiva do Visitante (PhD thesis), Universidade Fernando Pessoa, Porto.

- $\quad$ Figueiredo, H.M.G. (2013), 0 papel da animação turística na programação de atividades complementares ao alojamento: proposta de modelo de intervenção (Masters dissertation), Escola Superior de Gestão de Tomar, Tomar.

- Gokovali, U., Bahar, O. and Kozak, M. (2007),'Determinants of length of stay: A practical use of survival analysis',Tourism Economics, 14, 205222.

- Instituto de Planeamento e Desenvolvimento do Turismo (2018), Anuário de Tendências - Turismo'18, Caderno Especial, 25-65.
- Jacinto, P. (2003), Empresas de Animação Turística entre o Negócio e o Prazer (Masters dissertation), Universidade de Trás-os-Montes e Alto Douro, Vila Real.

- Jacobsen, J.K.S., Gossling, S., Dybedal, P. and Skogheim, T. S. (2018),'Exploring length of stay: International tourism in south-western Norway', Journal of Hospitality and Tourism Management, 35, 29-35.

- Pinto, S. (2009), Empresas de Hotelaria: uma análise económica e financeira (Masters dissertation), Instituto Superior de Ciências do Trabalho e da Empresa, Lisboa.

- Registo Nacional de Turismo, (2019),'Empreendimentos Turísticos', [Online], [RetrievedAugust 31, 2019], https://rnt.turismodeportugal.pt/RNET /Registos.ConsultaRegisto.aspx?Origem $=$ CP\&MostraFiltro $=$ True

- Rodrigues, S., Santos, E. and Oliveira, M, (2019), 'The offer of Tourist Routes to Increase Tourist Stay in Hotels',[Online], [Retrieved July 30, 2019], https://www.researchgate.net/publicat ion/324899777_The_Offer_of_Tourist_R outes_to_Increase_Tourist_Stay_in_Hotel $\mathrm{s}$

- Souza, G (2006), Hotelaria Hospitalar: Conceitos de hotelaria adaptados ao sector hospitalar (Bachelor'sthesis), Universidade Federal de Minas Gerais, Brasil.

- Torres, Z. (2004), Animação Turística,Editora Roca LTDA,São Paulo.

- Turismo de Portugal, IP. (2013),'Plano Estratégico Nacional do Turismo Revisão e objetivos 2013-2015',[Online], [RetrievedAugust 31, 2019], https://travelbi.turismodeportugal.pt/p $\mathrm{t}-$ pt/Documents/Estrat\%C3\%A9gia/PEN T_2014.pdf

- Vogel, H. L. (2014), Entertainment industry economics: A guide for financial analysis,Cambridge University Press,Cambridge.

- Xu, J. B. (2010),'Perception of tourism products',Tourism Management, 31, 607-610. 